\section{In memoriam}

Falar de Herculano de Carvalho, do nosso Professor Herculano, escassos dias após a sua derradeira viagem para longe de nós, é tarefa ingrata que de modo algum lhe poderá fazer justiça. Haverá que encetá-la mais tarde, com o tempo e a distância suficientes para poder fazer sobressair devidamente a sua superior figura humana e de cientista, o seu espírito sereno e sensível mas, simultaneamente, realizador e aberto às novas ideias e ao progresso.

Com o seu desaparecimento encerra-se um ciclo na História da química portuguesa - sentimo-lo aqueles que tivemos o privilégio de o ter como Mestre e senti-lo-ão decerto também os seus contemporâneos nas responsabilidades académicas. Todos, de uma forma ou de outra, beneficiámos da sua ajuda e da sua acção, decisiva no impulso à investigação científica em Portugal nas décadas de 50 e 60 . Soube criar, soube dirigir, soube dar oportunidades e soube retirar-se no momento próprio, deixando o caminho aberto às novas gera- çð̄es sem, todavia, deixar de se interessar por elas. E era com comovido respeito, admiração e saudade que até há poucos meses o víamos ainda no Instituto Superior Técnico, visitando o seu laboratório, perguntando por nós, informando-se e discutindo a nossa actividade com impressionante lucidez, trazendo-nos mesmo as suas últimas publicaçōes - úteis artigos, produto da sua experiência profissional e científica ou magnificas traduçōes para português dos grandes poetas universais...

Do que fez ao longo de muitos anos de permanente actividade dá conta o seu extenso "curriculum vitae", mas será difícil extrair da frieza das citaçð̋es e dos números os muitos exemplos de humanidade, dedicação ao trabalho, seriedade científica e profundidade cultural que nos legou, com os quais moldou as geraçð̄es que ensinou e verdadeiramente "formou" no sentido mais nobre da palavra.

J.J.R. Fraústo da Silva

\title{
Professor António Herculano de Carvalho
}

Quando o Director do “Técnico", com a sua Conklin preta, rubricava a folha onde eu começava a desenhar as curvas e contracurvas, rectas e concordâncias que, depois de cobertas a tinta da China com o tiralinhas "bico de pato", haveriam de decidir da aptidão do candidato para entrar no Instituto, mal sabia eu que esse Director era o Prof. Herculano de Carvalho e não poderia adivinhar que o conhecimento então travado iria a transformar-se em amizade e haveria de durar quase meio século.

Nascido em Coimbra, em 12 de Agosto de 1899, ainda no século em que os comboios começaram a circular, António Herculano Guimarães Chaves de Carvalho viria a viver intimamente a mutação que os primeiros três quartos deste século imprimiram ao mundo científico. Só daqui por muitos anos se avaliará correctamente o que foi a transformação que se operou durante este período, em que se passou do mundo de Júlio Diniz e Trindade Coelho para aquele que veio a conhecer o Prof. Herculano de Carvalho como Presidente da Comissão de Estudos de Energia Nuclear, nas décadas de cinquenta e sessenta.

Foi nesta Comissão, parte importante do Instituto de Alta Cultura, que ele teve oportunidade para "puxar", pela investigação científica, sobretudo em Química, o que veio a reflectir-se no grande número dos seus discípulos e dos discípulos dos seus discípulos que têm vindo a salientar-se, quer directamente no campo da Química científica, quer noutros campos sempre, mais ou menos, relacionados com investigação e ciência, educação e universidade.

E tinha já sido, de 1933 a 1948, Presidente da Direcção do Instituto Português de Combustiveis, onde durante todo o período da Segunda Guerra e- da consequente escassez de combustíveis, desenvolveu notável acção para que alguns veículos continuassem a locomover-se com os famosos gasogéneos que obrigavam a parar, de tantos em tantos quilometros, para "meter mais umas achas de lenha" e limpar os filtros. Mas andavam! Formado em engenharia químico-industrial no IST, com 18 valores, nunca abandonou a sua Escola, onde continuou a tarefa que tinha sido iniciada por Charles
Lepierre de quem foi notável colaborador e de quem sempre disse: "Fui discípulo de Lepierre".

O seu último cargo oficial foi o de Reitor da Universidade Técnica. Foi vogal de inúmeros conselhos e comissð̌es (1) e delegado em diversos organismos internacionais. Na Academia das Ciências de Lisboa ocupou a cadeira número um que pertencera a Achilles Machado. Possuia várias condecoraçðes (1), que muito prezava mas que nunca o vi usar.

A sua actividade científica ficou patente em perto de uma centena de artigos (2) publicados em diversas revistas nacionais e estrangeiras. Dois livros de versos (3 e 4) que publicou na juventude, tiveram continuidade anos mais tarde com poesias originais ou traduzidas de diversos idiomas $(5,6,7)$.

Acontecimentos ou impressōes de viagem levaram-no muitas vezes a traduzir em verso o seu sentimento, como é o caso de vários sonetos que escreveu a propósito da impressão que lhe causou a sua visita à Ilha de Moçambique, dos quais um termina com dois tercetos:
" $\mathrm{E}$ vede agora: o povo que isto fez é luz com sombra: tem dentro de si dois polos entre os quais sempre estremece.
Contraditória gente! Tanta vez
dormindo a sono solto... Pois aqui
só seu génio em vigília transparece!"

No fim do dia de Todos os Santos de 1986 terminou subitamente a vida do Prof. Herculano de Carvalho no local que ele mais amava e que era a sua terra de adopção, Tavira. O seu último dia foi vivido como ele sempre gostara: em paz entre os seus e apreciando os locais onde gostava de viver e caçar.

\section{BIBLIOGRAFIA}

Carlos Pulido

1. A Universidade Técnica de Lisboa e os seus Mestres - Lisboa, 1956 - ed.: Universidade Técnica de Lisboa.

2. Rev. Port. Quim., 11, 18(1969).

3. Romaria das Curvas (versos) - Coimbra, 1918.

4. No Domínio dos Símbolos (versos) - Coimbra, 1920.

5. Musa de Quatro Idiomas (versos-traduçðes) Ática, Lisboa (1945).

6. Circunstâncias (versos) - O oiro do dia, Porto (1981).

7. Oiro de Vário Tempo e Lugar - De São Francisco de Assis a Louis Aragon (versðes) - O oiro do dia, Porto (1983). 